\title{
MAKNA SIMBOLIK TOR-TO RSOMBAH DALAM UPACARAADAT KEMATIAN SAYUR MATUA PADA MASYARAKAT SUKU BATAK SIMALUNGUN
}

\author{
Febrina Athylata Purba \\ Program Pascasarjana \\ Institut Seni Indonesia Surakarta \\ JI. Ki Hadjar Dewantara No. 19 Kentingan, Jebres, Surakarta, 57126 \\ Email: nathylafelin04@gmail.com \\ Slamet \\ ISI Surakarta
}

\begin{abstract}
ABSTRAK
Penelitian yang berjudul "Makna Simbolik Tor-torsombah Dalam Upacara Adat Kematian Sayur Matua Pada Masyarakat Suku Batak Simalungun" merupakan bentuk pertunjukan tari yang terkait dalam upacara adat kematian sayur matua. Penelitian ini bertujuan untuk menggali makna simbolik Tor-tor Sombah dalam upacara adat kematian sayur matua, bagaimana hubungan antara Tor-tor Sombah Sombah dengan upacara adat kematian sayur matua pada masyarakat suku Batak Simalungun, serta bentuk pertunjukan Tor-tor Sombah Sombah dalam upacara adat kematian sayur matua. Permasalahan dalam penelitian ini diungkapkan dengan mendeskripsikan bentuk dari Tor-tor Sombah Tor-tor Sombah yang dilihat dari elemen-elemen koreografi dengan dibantu oleh notasi laban dan dianalisis dengan memakai teori dari Laban yaitu effort dan shape. Selain itu juga dalam penelitian ini bertujuan untuk menganalisis makna simbolis Tor-tor Sombah yang dilihat dari dua bagian yaitu aspek dalam dan aspek luar dengan konsep dari Allegra Fuller Synder. Adapun metode yang digunakan dalam pengumpulan data ini adalah metode kualitatif dengan pendekatan etnokoreologi. Teknik pengumpulan data lapangan menggunakan model dari Kurath dengan metode etnografi tari. Hasil penelitian menunjukan bahwa Tor-tor Sombah Tor-tor Sombah dalam upacara adat kematian sayur matua bagi masyarakat suku Batak Simalungun dilaksanakan sebagai penyampaian rasa hormat anak kepada orang tua yang sudah meninggal. Tor-tor Sombah dalam kehidupan masyarakat suku Batak Simalungun saling berkaitan dan merupakan bagian dari adat yang digerakkan secara simbolis pada upacara adat. Tor-tor Sombah memiliki makna dan simbol dalam unsur sajian yang ditampilkan yaitu: dalam gerak tangan, iringan musik, busana, tata rias, properti, dan umpasa. Gerakan pada tangan yang terdapat dalam Tor-tor Sombah mempunyai tiga bentuk, yaitu :sombah, mangalo-alo, mamasu-masu. Selain menunjukkan bahwa Tor-tor Sombah memiliki makna simbolik, berkaitan juga sebagai media komunikasi, dan melalui gerak yang disajikan terjadi interaksi antar peserta upacara. Tor-tor Sombah menjadi bagian dari kebudayaan yang berfungsi untuk menjaga serta mempertahankan kelangsungan sistem sosialnya pada masyarakat suku Batak Simalungun.
\end{abstract}

Kata kunci: or-tor Sombah, Upacara Adat Kematian Sayur Matua Batak Simalungun, Koreografi, Makna Simbolik.

\begin{abstract}
The study entitled "Makna Simbolik Tor-tor Sombah Dalam Upacara Adat Kematian Sayur Matua Pada Masyarakat Suku Batak Simalungun" is a form of dance performance concerning the traditional ceremony of Sayur Matua death. This study aims to explore the symbolic meaning of Tor-tor Sombah in Sayur Matua death ceremony, how the relationship between Tor-tor Sombah and the traditional ceremony of Sayur Matua death in Batak Simalungun tribe, as well as the form of Tor-tor Sombah performance at the ceremony of Sayur Matua death. The problems in this study are expressed by describing the form of Tor-tor Sombah Tor-tor Sombah which is seen from the choreographic elements through Laban notation and is analyzed by using Laban theories, namely effort and shape. In addition, this study also aims to analyze the symbolic meaning of Tor-tor Sombah based on the inner and outer aspects with the concept of Allegra Fuller Synder. The data is collected by using qualitative method with an ethnochoreological approach. The Field data collection uses models from Kurath through dance ethnographic methods. The results of the study show that Tor-tor Sombah in Sayur Matua death ceremony in Batak Simalungun tribe represents the delivery of children's respect towards their deceased parents. The Tor- tor Sombah is interrelated with the life of Batak Simalungun tribe and is part of the custom that is symbolically presented in traditional ceremonies. Tor-tor Sombah has meanings and symbols in the elements of presentation, namely: hand gestures, musical accompaniment, costume, make-up, property, and umpasa. There are three forms of hand gestures in the Tor-tor Sombah, namely: sombah, mangalo-
\end{abstract}




\section{GEEAR surmal saim iublya}

alo, mamasu-masu. Besides the symbolic meaning contained in Tor-tor Sombah, it also represents a medium of communication. The presented movement causes an interaction among the participants of the ceremony. The Tor-tor Sombah is part of a culture that serves to maintain the continuity of its social system in Batak Simalungun tribe.

Keywords: Tor-tor Sombah, Traditional Ceremony of Sayur Matua Death of Batak Simalungun, Choreography, Symbolic Meanings.

\section{A. Pengantar}

Tari adalah sebuah pertunjukan yang melibatkan seluruh elemen masyarakat pendukungnya. Tari diadakan sesuai dengan kebudayaan setempat dengan cara dalam konteks yang berbeda-beda. Tari diadakan untuk upacaraupacara yang berkaitan dengan adat dan kepercayaan, namun ada juga yang melaksanakannya sebagai hiburan atau rekreasi. Sistem sosial dan lingkungan alam yang mempengaruhi bentuk, dan makna tari pada suatu komunitas suku dan budaya.

Tari dalam masyarakat suku Batak Simalungun disebut dengan Tor-tor, dan sudah ada sejak abad ke-13 dan menjadi budaya dari suku Batak. Tor-tor untuk kehidupan suku Batak Simalungun yang merupakan adat dan hiburan, biasanya diiringi dengan alat musik tradisional, dan suara manusia. Gerakan tor-tor terdiri dari gerakan badan yaitu: gerakan kepala, penglihatan mata, ayunan tangan, jari-jari mangeper, eot, ondok, dan langkah. Gerakan tor-tor tersebut menunjukan keindahan, terutama bila si penari (panortor) melakukan gerakan tersebut dengan menggunakan perasaan, maka orang lain (penonton) yang melihatnya dapat menangkap pesan atau makna dari gerak tor-tor yang dilakukan oleh panortor tersebut.

Tor-tor Sombah untuk kehidupan masyarakat Batak Simalungun berhubungan erat dengan upacara adat, upacara ritual kematian sayur matua, maupun untuk hiburan. Tor-tor Sombah untuk kehidupan masyarakat Batak Simalungun mempunyai peranan penting sebagai aktivitas kehidupan yang berkaitan dengan kehidupan spiritual, dan hubungan sosial kemasyarakatannya. Tor-tor Sombah dilakukan dengan berbagai kegiatan ritual kematian sayur matua maupun upacara keagamaan, dan juga dapat dipertunjukan dalam konteks adat

Tor-tor Sombah adalah salah satu tarian tradisional suku Batak Simalungun, yang dapat ditarikan oleh pemuda-pemudi,dan orangtua. Menurut sejarah, Tor-tor Sombah ditampilkan kepada tamutamu kehormatan, dan kegiatan upacara adat yang diiringi dengan gonrang. Bila tor-tor ini telah selesai dipertunjukan maka tor-tor yang lain dapat ditampilkan sesuai dengan permintaan atau kebutuhan dari upacara adat dengan diiringi gual.

Tor-tor Sombah telah lama hidup di tengahtengah kehidupan masyarakat suku Batak Simalungun, dengan istilah Sombah yang artinya "sembah". Sombah pada zaman kerajaan di Simalungun, bila dapat dirubah, diganti, dan disesuaikan menurut keadaan sekarang yaitu Tor-tor Bolon/Tor-tor Agung. Bentuk gerak dari tor-tor sombah menunjukan kedua belah tangan menyembah kepada tamu pimpinan, cara penyembahan dengan menggunakan tangan. Gerakan dari Tor-tor Sombah bisa dilakukan dengan berbagai jenis variasi gerak yang dapat menambah nilai keindahan, supaya Tortor Sombah (tor-tor bolon/tor-tor ogung) ini benar-benar agung.

Perkataan sombah hendaknya dihindarkan/ dijauhkan, karena menurut keterangan dari para orang tua, bahwa yang disembah hanya Tuhan, manusia tidak disembah tetapi dihormati. Sebagai alatalat penggerak dalam Tor-tor Sombah ini diutamakan ialah gonrang, sarunei, mongmongan, ogung, dan sitalasayak. Bila gual itu diiringi dengan sarunei bolon dengan sigumbangi (sarunei dengan memakai sigumbangi, yaitu seruas bambu yang dibuat khusus untuk memperbesar resonansi suara sarunei).

Penyajian Tor-tor Sombah sering ditampilkan dalam upacara adat, upacara ritual, dan hiburan. Setiap penampilan dari Tor-tor Sombah jika tidak diiringi dengan sigumbangi, maka Tor-tor Sombah disebut tor-tor hear. Sebelum tor-tor dimulai biasa dilakukan oleh masyarakat suku Batak Simalungun lebih dahulu dipertunjukan ragam gual/sarunei, diperdengarkan tanpa tarian. Untuk sekarang ragam suara sarunei dimainkan terlebih dahulu, baru menyusul ragam suara gual, kemudian menari.

Kegiatan tersebut merupakan suatu pendahuluan dari upacara gonrang, supaya perkataan pada upacara diadakan sesungguhnya sehingga jalannya upacara dari awal sampai akhir dapat diikuti dengan khidmat oleh para peserta yang turut dalam upacara tersebut. Sebelum Tor-tor Sombah selesai 
ditampilkan oleh para panortor, maka para panortor lainnya telah bersiap-siap dan dapat mengikuti bunyi gonrang, sarunei, mongmongan, ogung.Tor-tor Sombah ditarikan dengan penuh penghayatan sehingga para panortor dapat mengikuti bunyi gonrang, ogung, mongmongan, terutama sarunei bolon, dengan tujuan agar para panortor dapat menunjukan makna dan keindahan dari Tor-tor Sombah yang ditampilkan.

Tor-tor sombah ditarikan sesuai dengan kedudukan masing-masing masyarakat dalam kehidupan adat suku Batak Simalungun dimana terdapat beberapa interaksi sosial antara unsur-unsur kekerabatan yang diatur berdasarkan Tolu Sahundulan Lima Saodoran. Tolu Sahundulan Lima Saodoran adalah sebagai sistem kemasyarakatan (sistem kekerabatan) suku Batak Simalungun. Konsep Tolu Sahundulan Lima Saodoran mengatur posisi partisipan upacara dalam acara adat yang berlangsung. Tolu Sahundulan Lima Saodoran merupakan tiga posisi penting dalam kekerabatan suku Batak yang dijunjung tinggi dan menjadi falsafah dalam kehidupan masyarakat Batak Simalungun.

Tor-tor sombah dalam kehidupan masyarakat suku Batak Simalungun saling berkaitan. Keterkaitan antara Tor-tor Sombah dengan masyarakat suku Batak Simalungun yaitu berhubungan dengan aktivitas pada upacara adat kematian sayur matua.Tor-tor sombah bagi masyarakat suku Batak Simalungun bukan hanya sekedar gerakan yang indah, tetapi harus berlandaskan falsafah kehidupan dan ritual serta merupakan bagian dari adat yang digerakkan secara simbolis.

Secara harafiah, gerakan Tor-tor Sombah merupakan gerakan tubuh manusia yang teratur, terlatih, yang kemudian menjadi kebiasaan yang diakui dan didukung. Setiap gerakan Tor-tor Sombah memiliki pola di dalam aturan-aturan dan nilai keindahan setempat yang dilakukan secara simbolis, dan memiliki makna-makna religius, yang bertujuan untuk menghormati arwah para leluhur. Sampai saat ini, Tortor Sombah terus hadir dalam setiap pesta adat bagi masyarakat suku Batak Simalungun, yaitu diantaranya pada pesta pernikahan, upacara Mangompoi Jabu, upacara Manulangi. Terjadi juga dalam upacara kematianserta upacara Mangongkal Holi.

Kehadiran upacara di dalam suatu lingkungan masyarakat merupakan ungkapan tertentu yang berhubungan dengan bermacam-macam peristiwa penting. Peristiwa-peristiwa penting tersebut dilaksanakan sebagai suatu upacara dengan rangkaian dan tatanan yang dijalankan sesuai dengan kepercayaan dan tradisi secara turun temurun. Seperti halnya Tor-tor Sombah dalam upacara adat kematian sayur matua bagi msyarakat suku Batak Simalungun. Upacara adat kematian sayur matua dilaksanakan sebagai penyampaian rasa hormat anak kepada orangtua yang sudah meninggal. Karena bagi masyarakat suku Batak Simalungun, orang tua diibaratkan sebagai wujud dari Tuhan yang kelihatan.

Tujuan dari upacara adat kematian sayur matua ini adalah untuk mengungkapkan perwujudan rasa gembira orang tua yang telah meninggal dengan penuh kemenangan atau sukses, karena telah beranak dan bercucu dalam arti mempunyai generasi penerus berikutnya. Sebab bagi masyarakat suku Batak Simalungun, Anak adalah harta yang paling berharga, dalam bahasa Bataknya "Anakkhonki do hamuraon di ahu" yang berarti anak-anakkulah hartaku yang paling berharga. Berdasarkan pemahaman tersebut, jelas bahwa pentingnya peran anak dalam upacara adat kematian sayur matua masyarakat suku Batak Simalungun.

Pada masyarakat Batak Simalungun, kematian (matei) di usia yang sudah sangat tua, merupakan kematian yang paling diinginkan. Terutama bila orang tua yang meninggal telah menikahkan semua anaknya dan telah memiliki cucu dari anakanaknya. Pelaksanaan upacara kematian adat sayur matua dengan menarikan tor-torsombah sebagai tarian untuk menghormati orang tua yang sudah meninggal, bagi keluarga yang berduka, Tuhan Yang Maha Esa, dan leluhur (nenek moyang). Tor-torsombah hadir dan menjadi bagian dari kesenian tradisi masyarakat suku Batak Simalungun yang merupakan suatu kegiatan ritual untuk selalu dibawakan pada setiap kegiatan upacara adat khususnya upacara adat kematian sayur matua. Tor-tor Sombah menjadi bagian dari kebudayaan bagi masyarakat suku Batak Simalungun yang berfungsi untuk menjaga serta mempertahankan kelangsungan sistem sosialnya.

Upacara adat kematian sayur matua pada masyarakat suku Batak Simalungun merupakan pengakuan bahwa masih ada kehidupan dibalik dunia ini. Pelaksanaan upacara adat kematian sayur matua sangat penting bagi masyarakat suku Batak Simalungun karena merupakan sebagai tanda penghormatan terakhir oleh orangtua yang meninggal dunia, keluarga yang telah ditinggalkan yaitu anakanak, cucu, sanak saudara.

Upacara adat kematian sayur matua untuk suku Batak Simalungun diiringi dengan alat musik gonrang bolon yang dimainkan di dalam ataupun di luar rumah, namun pada tempat yang berdekatan 


\section{GEEAR surmal sair iublya}

dengan jenazah. Alat musik gonrang berhenti dimainkan pada saat mendekati tengah malam, meskipun menurut tradisi yang asli, musik ini dimainkan sampai pagi. Mendekati senja hari setelah berlangsungnya upacara disertai dengan kata-kata sambutan, arak-arakan menuju lokasi penguburan mulai dilaksanakan dengan dipimpin oleh para pemain musik dan pengusung jenazah. Demikian seorang warga Simalungun dibaringkan ke peristirahatannya yang terakhir menurut tata cara yang digariskan oleh tradisi.

Upacara adat kematian sayur matua ini disertai dengan adanya penyerahan hewan ternak sebagai persembahan, dipilihnya hewan ternak karena yang meninggal sudah sempurna dalam adat yaitu sudah Sayur Matua. Seluruh rangkaian upacara sayur matua, dilaksanakan selama tiga sampai tujuh hari, untuk kegiatan upacaranya akan melibatkan banyak orang, dengan biaya yang cukup besar. Dengan adanya hubungan Tolu Sahundulan Lima Saodoranyang terbentuk keturunan sayur matua secara bersama akan menanggung biaya upacara tersebut.

Secara fisik Tor-tor Sombah merupakan tarian, namun memiliki makna yang lebih dari gerakangerakannya. Makna dan simbolik pada Tor-tor Sombah terdapat di dalam unsur sajian yang ditampilkan yaitu : iringan musik, busana, tata rias, dan properti, umpasa yang digunakan, serta kebiasaan yang dilakukan sebelum, pada saat dan selama pertunjukan merupakan tradisi yang terus menerus berlaku pada masyarakat suku Batak Simalungun. Untuk gerakan tari pada tangan yang terdapat dalam Tor-tor Sombah mengandung makna. Gerak tangan dalam menarikan Tor-tor Sombah mempunyai empat bentuk, yaitu : Sombah, Dihar, Mangalo-alo dan Mamasu-masu, Huda-huda/Toping-toping.

Selain menunjukan bahwa Tor-tor Sombah memiliki makna simbolik, dan berkaitan juga sebagai media komunikasi, karena melalui media gerak yang disajikan terjadi interaksi antar partisipan upacara. Dalam menari tor-tor, setiap partisipan upacara wajib menggunakan Ulos. Ada berbagai macam jenis Ulos Batak. Ulos yang digunakan dalam manortor harus disesuaikan dengan konteks acara adat yang diselenggarakan. Begitu pula dengan musik dan lagu yang mengiringi Tor-tor Sombah, dimana musik acara adat sangat berbeda dengan musik acara yang sifatnya hiburan, permintaan untuk musik acara adat disesuaikan dengan tema dari upacara adat, dan adanya peran dari tokoh adat yang memimpin upacara adat.
Peristiwa upacara adat kematian sayur matua memiliki kedudukan penting dalam kehidupan masyarakat Suku Batak Simalungun terkait dengan upacara kematian. Kehadiran Tor-tor Sombah dalam upacara adat kematian sayur matua tidak terlepas dari sistem kepercayaan masyarakat Simalungun dalam menghormati orang tua yang sudah meninggal untuk mengantarkan ke sorga. Kehadiran Tor-tor Sombah menjadikan upacara adat kematian sayur matua sempurna secara adat Simalungun.

Menelusuri kehadiran Tor-tor Sombah dalam upacara adat kematian sayur matua dan rasa ingin tahu tentang kebudayaan Batak Simalungun menyebabkan penulis ingin mempelajari lebih dalam mengenai segala bentuk budaya dan adat istiadat suku Batak Simalungun. Tor-tor Sombah yang merupakan bagian dari seni budaya dalam hal ini untuk upacara adat kematian sayur matua membuat timbul berbagai pertanyaan dalam pikiran penulis, dimana Tor-tor Sombah mampu menyampaikan makna-makna, dan berguna untuk melestarikan kebudayaan masyarakat suku Batak Simalungun sehingga mampu bertahan dengan bentuk tradisional di tengah zaman moderenisasi. Untuk mengetahui nilai, makna, bentuk serta hubungan dengan upacara adat kematian sayur matua, maka judul penelitian ini adalah "Makna Simbolik Tor-tor Sombah Dalam Upacara Adat Kematian Sayur Matua Pada Masyarakat Suku Batak Simalungun".

\section{B. Pembahasan}

\section{Tor-tor Sombah dalam upacara adat kematian sayur matua pada masyarakat suku batak simalungun}

a. Upacara Adat Kematian Sayur Matua suku Batak Simalungun

Kematian adalah salah satu bagian siklus lingkaran kehidupan seseorang yang paling akhir. Bagi masyarakat suku Batak Simalungun, upacara kematian menjadi penting karena bagian ini adalah akhir dari setiap kehidupan manusia, dan pasti akan dialami oleh setiap individu. Pandangan masyarakat suku Batak Simalungun terhadap peristiwa upacara adat kematian khususnya untuk sayur matua memiliki syarat-syarat yang harus dijalankan, karena tidak semua yang dapat meninggal secara sempurna (sayur matua).

Meninggal sebagai Sayur matua bagi masyarakat Batak Simalungun adalah suka cita dan kesempurnaan. Sayur matua adalah orang tua yang sudah meninggal dunia telah ber-anak cucu baik dari 
anak laki-laki maupun anak perempuan. Pelaksanaan upacara adat kematian sayur matua, harus dilalui beberapa tahapan, yaitu:(a). persiapan: Martonggo Raja, (b). pemotongan hewan kerbau, (c). perlengkapan upacara. Adapun pelaksanaan upacara adat kematian sayur matua adalah sebagai berikut:(1).Upacara di Jabu ( di dalam rumah), (2). Upacara Maralaman (di halaman rumah), (3). Pasca Upacara Kematian.

\section{b. Kedudukan Tor-tor Sombah dalam Upacara Adat Kematian Sayur Matua Suku Batak Simalungun.}

Tor-tor Sombah telah lama hidup di tengahtengah kehidupan masyarakat suku Batak Simalungun, dengan istilah Tor-tor yang artinya tarian, dan Sombah yang artinya "sembah". Tor-tor Sombah ditarikan sesuai dengan kedudukan masing-masing masyarakat dalam kehidupan adat suku Batak Simalungun dimana terdapat beberapa interaksi sosial antara unsur-unsur kekerabatan yang diatur berdasarkan prinsip Tolu Sahundulan dan Lima Saodoran.

Tor-tor Sombah dalam upacara adat kematian sayur matua bagi masyarakat suku Batak Simalungun dilaksanakan sebagai penyampaian rasa hormat anak kepada orangtua yang sudah meninggal.Tor-tor Sombah yang hadir dan berkembang di dalam masyarakat suku Batak Simalungun tidak pernah lepas dari masyarakat sebagai pendukungnya. Tor-tor Sombah dalam upacara adat kematian sayur matua pada masyarakat suku Batak Simalungun akan dijelaskan dengan model dari Talcott Parson dalam Harja W. Bacthiar (1985:66) merupakan suatu bentuk ekspresi budaya sebagai suatu sistem simbol yang terbentuk dari sistem kepercayaan, sistem pengetahuan, sistem nilai moral, dan ekspresi.

Tor- tor sombah hadir dan menjadi bagian aktivitas masyarakat suku Batak Simalungun sebagai wujud kegiatan ritual. Sebagaimana yang dijelaskan Synder bahwa tari adalah simbol kehidupan manusia yang merupakan aktivitas kinetik yang ekspresif (Synder dalam I Made Bandem, 1996:22). Oleh karena itu, tor- tor sombah dibagi menjadi tiga aspek dalam yang berkaitan dengan bentuk wujud tari yaitu stimulasi atau dorongan dalam bentuk penyembahan dan penghormatan (sombah) kepada Tuhan, raja atau ketua adat, orang tua yang didukung dengan simbol gerak sombah, kemudian transformasi atau perubahan dalam bentu baru yaitu kegiatan sombah dalam upacara adat kematian sayur matua yang menjadi aktivitas gerak, dalam kemanunggalan atau unity yang dirangkaikan dalam sebuah kegiatan upacara adat kematian sayur matua dan pertunjukan tari yang dinamakan Tor-tor Sombah .

\section{Koreografi Tor-tor Sombah dalam Upacara Adat Kematian Sayur Matua pada Masyarakat suku Batak Simalungun}

Koreografi Tor-tor Sombah dalam upacara adat kematian kematian sayur matua pada masyarakat suku Batak Simalungun yang secara keseluruhan berdasarkan elemen-elemen yang terkandung dalam koreografi. Koreografi yang dikenal sebagai sebuah penataan tentang tari dipertegas dengan pendapat dari Y. Sumandiyo Hadi menyatakan bahwa koreografi merupakan pemahaman terhadap sebuah penataan tari yang dapat dianalisis dari aspek isi, bentuk, maupun tekniknya, baik untuk tarian kelompok maupun tarian tunggal (Hadi, 2011:1).Adapun unsurunsur koreografi sebagai berikut:

\section{a. Judul Tari}

Tor-tor Sombah merupakan tarian tradisi masyarakat suku Batak Simalungun. Penamaan dari Tor-tor Sombah ini merupakan gabungan dari dua kata yaitu "tor-tor" dan "sombah". Tor-tor merupakan istilah untuk menyatakan gerak atau tari yang diucapkan dengan menggunakan bahasa daerah Simalungun. Sedangkan sombah merupakan gerakan tangan yaitu kedua telapak tangan yang menyatu dengan posisi berada di depan dada, diatas depan kening, dan merupakan gerak utama yang terdapat di dalam Tortor Sombah .

\section{b. Tema Tari}

Tor-tor Sombah dalam upacara adat kematian sayur matua pada masyarakat suku Batak Simalungun merupakan tarian yang bertemakan keagamaan dan upacara adat kematian. Tor-tor Sombah yang berada dalam di dalam masyarakat suku Batak Simalungun dijadikan sebagai salah satu media komunikasi dan simbol penghormatan kepada Tuhan Yang Maha Esa dan orang tua yang telah meninggal dunia, dan keluarga yang ditinggalkan.

\section{c. Deskripsi Tari}

Tor-tor Sombah dalam upacara adat kematian sayur matua pada masyarakat suku Batak Simalungun merupakan tarian tradisi dilakukan dengan posisi badan rendah (posisi saat melakukan sholat), posisi kedua tangan berada di depan dada yaitu posisi “Sombah", ditambah dengan adanya gerakan pencak silat (gerak dihar) yang dibawakan oleh penari laki-laki, dan para penari juga menggunakan 


\section{GEEAR Jumal sai isudya}

properti topeng (huda-huda/toping-toping)diiringi alat musik gonrang.

Tor-tor Sombah dalam upacara adat kematian sayur matua pada masyarakat suku Batak Simalungun terbagi menjadi empat bagian yaitu gerak sombah, gerak dihar (gerak pencak silat), gerak mangalo-alo, dan gerak huda-huda/toping-toping, keempat bagian tersebut mempunyai peranan masingmasing.Gerak sombah (sembah) merupakan bagian awal dari Tor-tor Sombah dalam upacara adat kematian sayur matua pada masyarakat suku Batak Simalungun. Gerak sombah merupakan gerak tangan yang terdiri dari gerak sombah debata, sombah adat, tolak bala/mangalo-alo. Gerak dihar (gerak pencak silat) merupakan bagian tengah yang dibawakan oleh penari laki-laki, gerak dihar ini memiliki makna untuk memiliki sikap berani dalam menghadapi segala rintangan. Selanjutnya gerak mangalo-alo merupakan gerakan untuk menerima berkat serta mengajak semua orang untuk turut mengambil bagian dalam kegiatan ritual upacara adat kematian sayur matua suku Batak Simalungu. Pada bagian penutup yaitu gerak huda-huda/toping-toping dimana para penari perempuan dan laki-laki memakai topeng, topeng tersebut digunakan oleh para penari memiliki makna untuk menghibur para keluarga yang mengalami musibah.

\section{d. Gerak}

Gerak mempunyai beberapa faktor dasar, yaitu bahan, tenaga, ruang, dan waktu.Gerak tari dalam elemen-elemen Tor-tor Sombah sesungguhnya bersifat sederhana, fleksibel, dan komunikatif terhadap masyarakat atau penonton yang menikmatinya.

Menjelaskan mengenai gerak yang terdapat di dalam Tor-tor Sombah dijelaskan dalam beberapa bagian, yang semua bagian tersebut merupakan bagian tari sebagai teks. Menurut Marry Alice Brennan dalam Prihartini, dkk menyebutkan dalam artikelnya menyinggung sebuah sistem analisis gerak yang sangat tekstual dalam presentasinya, namun memiliki kontesktual di dalam penentuan yang kualitas estetisnya. Istilah yang digunakan dalam pernyataan tersebut ialah Laban Movement Analysis (LMA).Brennan juga menjelaskan bahwa di dalam tari terdapat 'gaya' sebagai kualifikasi teknis dan estetis dapat dikenali seseorang dengan mampu merinci dua unsur kunci dalam LMA yakni effort dan shape (Brennan dalam Prihartini, dkk, 2012:24-25).

Menganalisis gerak menurut $Y$. Sumandiyo Hadi terbagi dalam beberapa bagian, yaitu motif gerak, gerak pokok, gerak penyambung, gerak pengulangan, klimaks, dan kesatuan (unity), dan penjelasannya sebagai berikut: Menganalisis motif gerak pembentuk Tor-tor Sombah dalam hal ini meminjam model dari Laban yaitu mengacu pada konsep effort dan shape pada analisis gerak. Konsep effort merupakan aksi ketubuhan, loncatan, gerak vertikal, gerak horizontal, tempo lambat cepat, sebagai suatu usaha. Shape atau bentuk gerak yang berupa motif gerak, pada penjelasan gerak pada Tor-tor Sombah meliputi lintasan gerak, volume gerak, dan level. Pada analisis gerak effort dan shape dapat diketahui pembentuk motif gerak yaitu pola gerak pokok, pola gerak selingan, dan pola gerak isian (Ann Hutchinson, 1970:12).

\section{e. Penari}

Penari menurut Bagong Kussudiardja sebagai pembawa tari. Penari harus bertanggung jawab terhadap tari yang dibawakan dalam setiap pertunjukan. Penari juga harus bersungguh-sungguh dalam menari, karena dari penari inilah nama akan membawa nama baik bagi dirinya sendiri maupun kepada penata tarinya (Kussudiardja, 2000:19).

Pada tari tradisi keutamaan pada "rasa" terlihat dari pengalaman penari dalam mengungkapkan rasa tersebut ke dalam tari. Tari tradisi yang mengutamakan isi serta teknis penggarapannya menuju kesempurnaan suatu ujud yang berujung pada bentuk yang indah (Soedarso Sp, 2006:171). Bentuk pertunjukan tari tidak dapat dipisahkan dari peran penari, karena melalui penarilah bentuk sajian tari itu ditampilkan, baik dalam bentuk fisik maupun bentuk ungkapnya (Widyastutieningrum, 2012:126).

Tor-tor Sombah dalam upacara adat kematian sayur matua suku Batak Simalungun para penari terbagi menjadi empat bagian. Masing-masing dari pelaku tersebut mempunyai peranan masing-masing dan bertanggung jawab dalam tari. Setiap pelaku di dalam Tor-tor Sombah harus mampu saling bekerja sama untuk mencapai kesempurnaan dalam menjalankan upacara adat kematian sayur matua. Para pelaku dalam Tor-tor Sombah pada upacara adat kematian sayur matua suku Batak Simalungun terdiri dari (1) ketua adat, (2) pihak Hula-hula dan sanina, (3) pihak anak dan boru, (4) pemain musik, (5) masyarakat. Penari dalam upacara adat kematian sayur matua suku Batak Simalungun merupakan peserta upacara itu sendiri. Para penari Tor-tor Sombah dalam upacara adat kematian sayur matua suku Batak Simalungun juga terbagi menjadi beberapa bagian, yaitu (1) penari sombah, (2) penari dihar, (3) penari huda-huda/toping-toping, (4) penari mangalo-alo. 


\section{f. Tipe Tari}

Tipe tari merupakan jenis tarian seperti apa yang ada dalam suatu tari tersebut. Tipe tari menurut Elizabeth R. Hayes dalam Y. Sumandiyo Hadi terbagi kepada dua jenis yaitu kelompok kecil atau smallgroup dan kelompok besar atau large-group (Hayes, 2003:2). Tor-tor Sombah termasuk dalam tipe tari kelompok besar. Tari berkelompok merupakan tari yang memiliki jumlah penari lebih dari lima orang. Menurut Sal Murgiyanto, tari berkelompok harus selalu sederhana, dilakukan serempak, dan utuh (Murgiyanto, 1983:82).

Pendapat dari Sal Murgiyanto di atas dilihat dari bentuk Tor-tor Sombah , gerakan yang ada di dalam tarian ini mempunyai gerakan yang sederhana. Gerakan yang sederhana dilakukan secara serempak oleh para penari untuk dapat saling bekerja sama, sehingga tarian tersebut dapat dilihat secara utuh.

\section{g. Musik Tari}

Irama musik dalam seni tari selain sebagai pengiring tari juga untuk mempertegas gerak, memberi gambaran suasana, dan merangsang munculnya gerak. Hagualon adalah jenis atau style dalam gonrang Simalungun. Hagualon berasal dari kata "gual" (tabuh) bisa diartikan tata cara memukul (menabuh) gonrang atau jenis irama pukulan padagonrang dengan rumustertentudan tetap (tidak bisa diubah-ubah).

Gonrang adalah gendang. Orang Simalungun menyebutnya gonrang sedangkan, orang Batak Toba menyebutkan dengan istilah gondang. Peralatan gonrang Simalungun adalah terdiri dari: Gonrang (gonrang sidua-dua, gonrang sipitu-piti, gonrang bolon). 1. Gonrang Bolon

2. Dua buah Ogung (Gong)

3. Dua buah Mongmongan (Kenongan)

4. Satu buah Sarunei (Serunai).

5. Sitalasayak

Ansambel musik gonrang yang tersusun atas sebuah sarunei, dua buah alat tabuh yaitu Gonrang sidua-dua, satu buah Mongmongan, dan sebuah tawak-tawak atau siappuk (Gong bernada tinggi). Gual yang digunakan dalam Tor-tor Sombah adalah gual bolon.

\section{h. Tata Busana}

Tata busana yang dapat dilihat secara umum di lingkungan masyarakat suku Batak Simalungun adalah menggunakan pakaian adat Simalungun, dan melihat corak warnanya disesuaikan dengan kebutuhan dari penggunaan tata busana dalam acaraacara yang bersifat sakral, formal, dan hiburan. Ada perbedaan penggunaan tata busana antara pria dan wanita dalam Tor-tor Sombah untuk disajikan sebagai bentuk pertunjukan dan untuk busana upacara adat kematian sayur matua.

Penggunaan tata busana untuk upacara adat kematian sayur matua para penari dan peserta upacara yang wanita memakai baju atau kebaya berwarna hitam, begitu juga dengan pria. Untuk penutup kepala pada pria (gotong) diikatkan kain berwarna putih yang memiliki simbol adalah merupakan bagian keluarga yang mengalami kemalangan (ada salah satu anggota keluarga yang meninggal dunia). Para penari menggunakan topeng yang menyerupai wajah wanita (toping naboru) dan wajah laki-laki (toping dalahi), dan para penari tidak menggunakan riasan wajah. Kedua topeng memiliki rambut yang terbuat dari ijuk, tapi beda topeng laki-laki dan perempuan.

Penari huda-huda menggunakan kain putih yang menutupi setengah badannya dan dikepala menggunakan paruh burung enggang. Busana yang digunakan penari toping dalahi yaitu celana panjang hitam, suri-suri berwarna biru gelap, hiou berwarna biru gelap juga dengan motif ragei sattik, dan baju polangpolang (warna belang- belang kotak terdiri dari warna hitam, putih, merah) dan membawa bahul-bahul (kantong anyaman yang diselempangkan) guna untuk menerima uang dari para keluarga yang menyaksikan. Busana penari toping naboru adalah menggunakan suri-suri berwarna merah, hati rongga berwarna merah, baju polang-polang, dan membawa bahul-bahul. Sedangkan untuk penari huda huda hanya menggunakan kain penutup dari atas kepala sampai mata kaki yang berwarna sama seperti baju polangpolang yaitu putih, merah dan hitam dan membawa padung ni onggang (paruh burung enggang).

\section{i. Tata Cahaya}

Tata cahaya panggung atau stage lighting merupakan bagian dari tata teknik pentas yang spesifikasinya mengenai pengetahuan teori dan praktek membuat desain pencahayaan panggung (Martono, 2010:1).

Pertunjukan Tor-tor Sombah dalam upacara adat kematian sayur matua pada masyarakat suku Batak Simalungun setiap penampilannya baik di dalam maupun di luar gedung selalu memakai tata cahaya general light. Tata cahaya general light merupakan cahaya tampak yang tampak seluruh panggungnya. Tata cahaya general light dipakai dalam pertunjukan Tor-tor Sombah semakin menambah energi para 


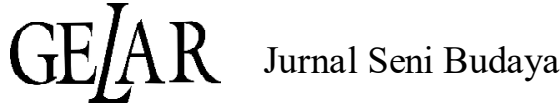

penari. Tata cahaya seperti ini mampu menciptakan suasana yang dekat dengan penontonnya.

\section{j. Properti}

Properti merupakan alat yang dipakai dalam satu pertunjukan tari. Pada upacara adat kematian sayur matua, properti yang digunakan oleh para penari ialah menggunakan padung ni onggang (paruh burung enggang), menggunakan toping (topeng), menggunakan bahul-bahul (kantong anyaman) yang dislempangkan dibahu penari, yang kegunaannya untuk menerima uang dari para penonton, khususnya dari mereka yang memiliki ikatan dengan keluarga yang bersangkutan.

\section{k. Tata Panggung}

Tata panggung merupakan sebuah tempat yang dipakai dalam satu bentuk pertunjukan.Tata panggung terdiri atas dua bagian, yaitu: outdoor(luar) dan indoor (dalam). Pembagian stage panggung tersebut mempunyai kelebihan.

Pertunjukan Tor-tor Sombah dalam upacara adat kematian sayur matua pada masyarakat suku Batak Simalungun menggunakan tata panggung terbuka yaitu di halaman rumah atau lapangan. Melihat dari betuk pertunjukan Tor-tor Sombah dalam upacara adat kematian sayur matua pada masyarakat suku Batak Simalungun menuntut memakai tata panggung yang luas bertujuan agar para masyarakat yang ikut berpartisipasi.

\section{Durasi}

Durasi dalam suatu pertunjukan merupakan waktu yang dari suatu penampilan yang dipentaskan. Durasi dalam suatu pertunjukan memiliki waktunya masing-masing. Durasi maksimal dari suatu pertunjukan adalah 15 menit sampai 60 menit.

Tor-tor Sombah dalam upacara adat kematian sayur matua pada masyarakat suku Batak Simalungun memiliki cara yang untuk menempuh waktu secara efektif. Dalam berbagai kesempatan seperti festival tari tradisi, pada acara undangan, dan acara pertandingan Tor-tor Sombah semuanya memiliki waktu yang khusus.

\section{m. Pola lantai}

Tor-tor Sombah dalam upacara adat kematian sayur matua pada masyarakat suku Batak Simalungun memiliki pola lantai. Pola lantai yang terlihat dalam Tor-tor Sombah dalam upacara adat kematian sayur matua pada masyarakat suku Batak Simalungun berbentuk garis lurus yang saling berhadapan, dan dibagi menjadi dua baris. Pola lantai yang seperti dalam Tor-tor Sombah terlihat diseluruh tari tradisi yang ada di Simalungun. Penari dari Tor-tor Sombah mempunyai posisi bersujud dan menyembah yang sejajar, dan untuk setiap kesempatan pola lantai Tor-tor Sombah dalam upacara adat kematian sayur matua pada masyarakat suku Batak Simalungun tidak ada yang berubah.

\section{Makna Simbolik Tor-tor Sombah dalam Upacara Adat Kematian Sayur Matua}

Makna dari Tor-tor Sombah merupakan bentuk simbolik masyarakatnya yang diungkapkan di dalam gerak, jumlah penari, syair yang dibawakan, dan lainnya. Analisis makna Tor-tor Sombah menggunakan model Allegra Fuller Synder dalam I Made Bandem yang memberikan pengertian bahwa tari adalah merupakan simbol kehidupan manusia, dan merupakan aktivitas kinetik yang ekspresif, termasuk pada aspek dalam (stimulus, transformasi, dan kemanunggalan), dan aspek luar (masyarakat dan lingkungan sekitar) (Bandem, 1996: 22).Analisis menjelaskan tentang penampilan Tor-tor Sombah sebagai sebuah pertunjukan yang didalamnya memiliki nilai berupa pemaknaan atau isi dari Tor-tor Sombah, sedangkan ekspresi diwujudkan dalam bentuk tari Tor-tor Sombah terutama dalam gerak dan syair.

Tor-tor Sombah lahir dalam lingkungan masyarakat suku Batak Simalungun bukan hanya sebagai sebuah ungkapan seni, tetapi sebagai media upacara adat dan agama, jumlah penari yang tak terbatas jumlahnya, syair yang dibawakan, pola lantai, dan lainnya. Sedangkan dorongan dari luar sangat dipengaruhi oleh masyarakat dan lingkungan, terutama sistem kepercayaan dan sistem kekerabatan. Penjelasan ini seperti yang dikemukakan oleh Allegra Fuller Synder, bahwa tari adalah simbol kehidupan manusia dan merupakan aktivitas kinetik yang ekspresif. Penjelasan analisis makna tersebut, berdasarkan ungkapan Allegra Fuller Synder bahwa kehidupan manusia dalam sistem simbol tari merupakan kinetik dan ekspresif. Dalam hal ini yang menjadi dua bagian penting yang membentuk Tor-tor Sombah yaitu aspek dalam dan aspek luar.

\section{a. Aspek Dalam}

Pada aspek dalam tersebut terdapat tiga bagian penting yaitu

1). Stimulasi (stimulation).

Stimulasi merupakan rangsangan yang timbul dari dalam suatu tarian. Tor-tor Sombah terstimulasi 
karena alasan agama yang membentuk suatu unsurunsur tari.

Tor-tor Sombah memiliki beberapa unsur di dalamnya, yaitu (1) penari, (2) koreografi, (3) syair, (4) pola lantai, (5) tata busana dan tata rias, dan (6) musik, transformasi (transformation), dan kemanunggalan (unity).

\section{2). Transformasi (transformation)}

Transformasi merupakan suatu perubahan dari satu bentuk lama ke bentuk yang baru. Perubahan yang terjadi merupakan bagian yang baru dari bentuk yang lama. Transformasi ini dikutip dalam I Made Bandem pada buku The Random Dictionary of English Languege, Unabridge sebagai "change in form, appearance, nature or character" yang artinya (perubahan bentuk, penampilan, situasi, atau karakter) (Bandem, 1996: 24).

Tor-tor Sombah yang hadir di dalam upacara adat kematian sayur matua pada masyarakat suku Batak Simalungun dapat dilihat dari beberapa bagian untuk proses tansformasi. Pertama, suatu kegiatan ritual dalam upacara adat kematian sayur matua yang dijalankan oleh masyarakat suku Batak Simalungun, kemudian ditransformasikan menjadi kesenian tari yaitu Tor-tor Sombah. Tor-tor Sombah merupakan tarian yang dibawakan sebagai bentuk penghormatan terhadap Tuhan, Raja, tokoh adat, orang tua, dan tamutamu kehormatan yang sampai saat ini dilakukan oleh masyarakat suku Batak Simalungun. Kedua, masyarakat merupakan orang-orang yang ikut terlibat langsung dalam kegiatan tor-tor pada pesta adat perkawinan, kematian, dan melalui tor-tor masyarakat akan memposisikan diri mereka berdasarkan struktur masyarakat dan sistem kekerabatan yaitu Tolu Sahundulan dan Lima Saodoran pada masyarakat suku Batak Simalungun. Sistem kekerabatan adalah suatu hubungan erat antara individu dengan individu, antara invidu dengan kelompok, atau antara kelompok dengan kelompok. Hal tersebut terjadi adalah sebagai akibat adanya hubungan darah atau dengan pernikahan.

Ketiga, koreografi yang terlihat dalam Tor-tor Sombah Batak Simalungun yaitu tangan, badan, kaki, dan kepala digerakan seturut dengan irama gonrang (gendang).Keempat, sajian bentuk pola lantai yang berbentuk lingkaran ditransformasikan menjadi pola segaris lurus. Pola lingkaran ini merupakan sajian yang terdapat dalam kegiatan upacara adat kematian sayur matua Batak Simalungun. Pola lingkaran ditransformasikan ke dalam Tor-tor Sombah pada upacara adat kematian sayur matua menjadi pola baru yaitu segaris. Pola segaris ini merupakan satu bentuk representasi dari masyarakat suku Batak Simalungun terhadap kesenian yang berakar dari kegiatan keagamaan dan adat-istiadat. Kelima, tata busana yang terlihat dalam upacara adat kematian sayur matua terikat dengan adat-istiadat yang berlaku dalam masyarakat. Busana yang dipakai di dalam beberapa pertunjukan tari tradisi khususnya di dalam Tor-tor Sombah pada upacara adat kematian sayur matua adalah busana tradisional suku Batak Simalungun. Busana yang dipakai oleh penari dalam Tor-tor Sombah digunakan sesuai dengan busana tradisional yang memiliki makna yaitu dari warna busana, gaya berbusana, penggunaan bulang dan gotong, motif ulos dan suri-suri yang digunakan.

Warna busana yang dipakai dalam Tor-tor Sombah pada upacara adat kematian sayur matua adalah warna hitam. Warna hitam memiliki makna sebagai simbol duka cita, kesedihan, dan kehilangan. Gaya berbusana yang dipakai para penari Tor-tor Sombah mencerminkan adat-istiadat suku Batak Simalungun. Busana yang dipakai dalam Tor-tor Sombah harus tertutup, tidak membentuk lekukan tubuh. Busana yang dipakai para penari Tor-tor Sombah juga dipakai oleh seluruh peserta upacara adat kematian sayur matua suku Batak Simalungun.

Penggunaan bulang dan gotong yang dipakai oleh penari dan peserta upacara adat kematian sayur matua memiliki makna sebagai simbol bahwa dirinya berasal dari suku Batak Simalungun. Gotong merupakan penutup kepala yang dipakai oleh kaum laki-laki terbuat dari kain batik berbentuk segitiga berwarna coklat. Bulang merupakan penutup kepala yang dipakai oleh kaum wanita terbuat dari benang wol yang dirajut berbentuk trapesium dan memiliki banyak warna. Gotong dan bulang selalu digunakan bersama dengan ulos dan suri-suri dalam upacara adat pernikahan maupun upacara adat kematian sayur matua suku Batak Simalungun.

\section{3). Kemanunggalan (Unity)}

Tor-tor Sombah merupakan salah satu tarian tradisi yang lahir, tumbuh, tetap bertahan sampai sekarang, dan menjadi bagian masyarakat suku Batak Simalungun. Dilihat dari beberapa unsur yang dijelaskan sebelumnya bahwa Tor-tor Sombah mengalami kemanunggalan (unity) dari masyarakatnya terbagi menjadi beberapa bagian, yaitu: Pertama, dari suatu kegiataan keagamaan, penyembahan dan penghormatan kepada Tuhan, raja, ketua adat, orang tua sebagai dasar dari keseniannya menjadi satu bentuk tari yang bernama Tor-tor Sombah. Kedua, para penari bisa dilakukan oleh penari laki-laki maupun 


\section{GEEAR Jumal sai isulya}

wanita, bahkan orang tua, dan jumlah penari tidak ditentukan. Ketiga, koreografi dalam Tor-tor Sombah terlihat dalam empat bagian yaitu gerak tangan (sombah), gerak kaki, gerak badan, dan gerak kepala. Keempat, syair yang terdapat di dalam Tor-tor Sombah ditentukan oleh ketua adat dan permintaan dari peserta upacara adat. Kelima, tata busana yang dipakai dalam Tor-tor Sombah adalah pakaian tradisional asli dari suku Batak Simalungun, yang memiliki corak dan warna yang beraneka ragam yang disesuaikan dengan kebutuhan dari setiap permintaan dari ketua adat yang menyelenggarakan upacara. Keenam, musik yaitu dari vokal (suara), permainan alat musik tradisional dari suku Batak Simalungun (gual). Secara bentuknya, Tortor Sombah merupakan tarian adat untuk mengiringi upacara-upacara adat, acara-acara resmi. Kini Tor-tor Sombah hadir di dalam kehidupan masyarakat sebagai bentuk pertunjukan seni dan hiburan yang dapat dinikmati, dan Tor-tor Sombah juga menyampaikan pesan bagi masyarakat.

\section{b. Aspek Luar}

Aspek luar merupakan pembahasan mengenai konteks-konteks dari simbol-simbol yang terlihat dari aspek dalam yaitu unsur-unsur yang terdapat pada Tor-tor Sombah. Aspek luar menurut Synder dalam Bandem (1996:22) dikatakan bahwa bagaimana kesenian-kesenian tersebut berada dalam masyarakat dan lingkungannya (Bandem, 1996:25).

Aspek luar dari kesenian ini sangat dipengaruhi oleh masyarakatnya. Unuk penjelasan mengenai aspek luar pada Synder akan dikaitkan dengan sistem simbol budaya yang terlihat pada konsep Parson dalam Bachtiar (1985) yang terdiri atas tiga bagian, yaitu: (1) sistem konstitutif dilihat dalam sistem kepercayaan, (2) sistem pengetahuan, (3) sistem nilai moral, (4) ekspresi yang merupakan bentuk dari Tortor Sombah dalam upacara adat kematian sayur matua telah menjadi bagian dari representasi budaya masyarakat suku Batak Simalungun.

Pertama, simbol konstitutif yang terbentuk sebagai ritual, penyembahan, penghormatan, kepercayaan yang merupakan inti dari agama. Hal ini terlihat di dalam Tor-tor Sombah terhadap kehidupan agama pada masyarakat suku Batak Simalungun, dimana masyarakat suku Batak Simalungun sampai saat ini memegang penuh nilai luhur Habonaron do Bona.

Kedua, simbol-simbol yang membentuk ilmu pengetahuan pada Tor-tor Sombah yaitu syair, pola lantai, dan musik. Ketiga bagian yang terdapat di dalam pengetahuan diberikan kepada masyarakat.
Syair-syair yang terdapat pada Tor-tor Sombah dalam upacara adat kematian sayur matua berisikan pesan, pantun (umpasa), nasehat, kritikan kepada masyarakat. Semuanya itu dapat disampaikan melalui syair lagu yang dinyanyikan oleh penyanyi yang dipilih untuk menyanyikan syair lagu dengan diiringi alat musik gonrang dan sarunei (gual). Melalui syair lagu ini yang sebagai salah satu alat komunikasi non verbal kepada masyarakat. Pola lantai, merupakan pemaknaan atas pembelajaran, pembinaan, penyampaian secara cepat kepada masyarakat. Melalui pola lantai dapat menyampaikan pesan yang sederhana dan dapat dengan mudah diterima oleh masyarakat.

Ketiga, simbol-simbol penilaian moral yang membentuk nilai dan aturan-aturan. Simbol-simbol yang membentuk penilaian moral dalam Tor-tor Sombah terlihat pada bagian koreografi dan pemakaian tata busana.Pada bagian koreografi terlihat pada bagian gerak tangan, yaitu: sombah, mangalo-alo, mamasumasu, gerak kaki: Serser, Ondok, gerak badan: gerakan kenjot, dan gerakan badan. Ke empat bagian itu mempunyai pemaknaan mengajarkan kepada kita untuk selalu menyembah, percaya, dan berdoa kepada Tuhan, saling menghormati, saling menolong, saling peduli terhadap keluarga dan sesama, saling mengasihi, dan semua manusia itu sama dihadapan Tuhan. Semua sikap ini tercermin di dalam Tor-tor Sombah pada upacara adat kematian sayur matua suku Batak Simalungun. Tata busana juga memiliki pemaknaan atas penanaman nilai moral oleh masyarakat suku Batak Simalungun dalam menjalankan ajaran agama dan adat-istiadat. Pemakaian tata busana ditempatkan sesuai dengan pelaksanaan upacara adat yang dijalankan, secara khusus mencerminkan budaya khas adat suku Batak Simalungun. Hal ini terlihat dari pemakaian busana oleh para penari Tor-tor Sombah dan para peserta upacara adat kematian sayur matua yang sesuai dengan aturan-aturan dari adat-istiadat suku Batak Simalungun, dan untuk kebutuhan pertunjukan dan hiburan pemakaian kostum dikemas lebih menarik dari segi warna dan corak tetapi tidak melanggar dari aturan-aturan adat-istiadat yang telah diterapkan oleh masyarakat suku Batak Simalungun. Adanya pemakaian aksesoris/perhiasan dapat menambah nilai keindahan (estetika) yang disesuaikan dengan karakter para penari dan tema dari upacara adat yang dijalankan, serta dalam hal pertunjukan seni tari.

Tor-tor Sombah dalam upacara adat kematian sayur matua merupakan tarian tradisional dari Batak Simalungun yang mempunyai keistimewaan dan 
keunikan untuk menyampaikan makna dalam tarian, dan juga menjadi proses pemberian dan penerimaan adat dalam sistem kekerabatan melalui komunikasi nonverbal yang menggunakan simbol-simbol. Penyampaian makna yang tampak dari pertunjukkan Tor-tor Sombah dalam upacara adat kematian sayur matua kepada peserta upacara dan para kerabat melalui proses interaksi simbolik.

\section{Kesimpulan}

Masyarakat suku Batak Simalungun menjadikan kesenian sebagai bagian dari kehidupannya. Seni yang hadir di dalam masyarakat suku Batak Simalungun menciptakan suatu hubungan interaksi satu dengan yang lain dan merupakan bagian dari proses keberlangsungan hidup. Berdasarkan penelitian dan hasil analisis terhadap Tor-tor Sombah dalam upacara adat kematian sayur matua dapat disimpulkan sebagai berikut :

\section{KEPUSTAKAAN}

Abdullah, Taufik. Di Sekitar Komunikasi llmu dan Seni, Analisis Kebudayaan. 2008.

Alfian, "Persepsi Masyarakat Tentang Kebudayaan Kumpulan Karangan," dalam Harsja W. Bachtiar, Birokrasi Dan Kebudayaan. Jakarta: PT. Gramedia, 1985.

Bandem, I Made. Etnologi Tari Bali. Pustaka Budaya, 1996.

Hadi, Y. Sumandiyo. Aspek-aspek Dasar Koreografi Kelompok. Yogyakarta: Multi Grafindo, 2003.

Kajian Tari Teks dan Konteks. Yogyakarta: Press FSP ISI Yogyakarta, 2007.

Pustaka, 2007.

Sosiologi Tari. Yogyakarta:

Seni Pertunjukan Dan Masyarakat Penonton. Yogyakarta: ISI Yogyakarta, 2012.

Hutchinson, Ann. Labanotation or Kinetography Laban The System Of Analyzing and Recording Movement. New York: A Theatre arts books, 1954-1970.
Martono, Hendro. Mengenal Tata Cahaya Seni Pertunjukan. Yogyakarta: Padepokan Press, 2000.

Morris, Desmond. Manwatching A Field Guide to Human Behavior. Harry N. Abrams, New York: INC, Publisher, 1997.

Murgiyanto, Sal. Koreografi Pengetahuan Dasar Komposisi Tari. Departemen Pendidikan Dan Kebudayaan, 1983.

Purba, Mansen dan Oji E. Saragih, Horja Sayur Matua. Medan: Bina Budaya Simalungun, 1994.

Purba, Rudolf dan J.E. Saragih. Peradaban Simalungun. Pematang Siantar: Komite Penerbit Buku Simalungun (KPBS), 2011.

Pramutomo, R.M. Antropologi Tari Sebagai Basis Disiplin Etnokoreologi. Surakarta: ISI Press, 2005.

. Etnokoreologi Nusantara Batasan Kajian Sistematika Dan Aplikasi Keilmuannya. Surakarta: ISI Press, 2007. Etnokoreologi Seni Pertunjukan Topeng Tradisional Di Surakarta, Yogyakarta, Dan Malang. Surakarta: ISI Press, 2011.

Ratna, Nyoman Kutha. Metodologi Penelitian Kajian Budaya dan Humaniora Pada umumnya. Yogyakarta: Pustaka Pelajar, 2010.

Royce, Anya Peterson. Antropologi Tari. Terj F.X Widaryanto. Bandung: Sunan Ambu Press, 2007.

Simatupang, Defri Elias, "Upacara Saur Matua : Konsep Kematian Ideal Pada Masyarakat Batak (Studi Etnoarkeologi)." Jurnal :Balai Arkeologi. Medan. 2012.

Sinaga, Salmon. Adat Ni Simalungun. Pematang Siantar: Partuha Maujana, 2002.

Sedyawati, Edi. Pertumbuhan Seni Pertunjukan. Jakarta: Sinar Harapan, 1981.

Sumardjo, Jakop. Filsafat Seni. Bandung: ITB Bandung, 2000.

Slamet, Barongan Blora Menari Di Atas Politik Dan Terpaan Zaman. Surakarta: Citra Sains LPKBN Surakarta, 2012. 